\title{
Synthetic Oviductal Fluid Medium with Isologous Oviductal Epithelial Cells Improves the Development of In Vitro Produced Nili Ravi Buffalo (Bubalus bubalis) Embryos
}

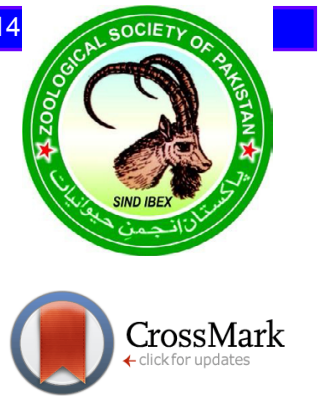

\author{
Asima Azam ${ }^{1}$, Asma-Ul-Husna ${ }^{2}$, Saima Qadeer ${ }^{3}$, Qaisar Shahzad ${ }^{4}$, Rabea Ejaz ${ }^{1}$, \\ Nemat Ullah ${ }^{5}$, Tasneem Akhtar ${ }^{4}$ and Shamim Akhter ${ }^{2, *}$ \\ ${ }^{I}$ Department of Zoology, Shaheed Benazir Bhutto Women University, Peshawar 25000 \\ ${ }^{2}$ Animal Physiology Laboratory, Department of Zoology, PMAS-Arid Agriculture \\ University, Rawalpindi 46300 \\ ${ }^{3}$ Department of Zoology, University of Education, Jauharabad Campus, \\ Jauharabad-41200 \\ ${ }^{4}$ Buffalo Research Institute Pattoki, Kasur, Lahore 54000 \\ ${ }^{5}$ Department of Animal Reproduction, Riphah International University, Lahore 54000
}

\begin{tabular}{l} 
Article Information \\
Received 09 March 2018 \\
Revised 30 April 2018 \\
Accepted 15 May 2018 \\
Available online 07 August 2019 \\
Authors' Contribution \\
\hline AA, SA and QS planned and executed \\
the project. AA, SA, AUH, SQ, RE \\
analyzed the results and wrote the \\
manuscript. NU and TA provided \\
technical assistance. SA supervised the \\
whole project. \\
Key words \\
Buffalo, Oviductal cell, Co-culture, \\
Conditioned media, IVF.
\end{tabular}

A B S T R A C T

The objective of the current study was to investigate and compare the role of buffalo oviductal epithelial cell (BOEC) co-culture and conditioned culture media, on in vitro development of Nili Ravi buffalo embryos. Oocytes were obtained from the ovaries of slaughtered buffaloes within two hours after slaughter and brought to laboratory. After in vitro maturation (IVM) in Tissue Culture Medium-199 (TCM199) for $24 \mathrm{~h}$ and fertilization (IVF) in Tyrode's Albumin Lactate Pyruvate (TALP) medium for about $20 \mathrm{~h}$, the presumptive zygotes were randomly distributed into 6 culture groups; Group I: Synthetic Oviductal Fluid (SOF) medium alone, Group II: SOF + co-culture, Group III: Conditioned SOF, Group IV: M199 alone, Group V: M199 + co-culture and Group VI: Conditioned M199 for in vitro culture (IVC). The percentage of embryos capable of crossing 8-16 cell block and reaching morula stage were higher $(\mathrm{P}<0.05)$ in Group II and Group III compared to other treatments. Both treatment groups were equally effective $(\mathrm{P}>0.05)$. Results also indicated that synthetic oviductal fluid (SOF) medium was found better than M199 when co-cultured and conditioned with buffalo oviductal epithelial cells for culturing buffalo embryos. Conditioned SOF is recommended to be used as IVC media in future studies as it eliminates contamination problem, remove batch to batch variation, long-lived and is readily available.

\section{INTRODUCTION}

A mong the highest milk-producing breeds of buffalo, Nili Ravi is the principle breed in Pakistan. Although, this breed has potential to produce more than 5000 liters of milk/lactation (Bilal et al., 2006), the milk yield of this breed is no more than 1800-2500 liters/lactation. The reason is poor genetic selection that can be improved by technologies like artificial insemination and in vitro embryo production/transfer but so far AI has met little success (Asma-ul-Husna et al., 2017). In vitro embryo production (IVEP) that extends the genetically superior male and female germ-plasm simultaneously is the widely accepted assisted reproductive technique around the world but not yet has been optimized for Nili Ravi buffalo. It is relevant to mention that previous studies conducted on Nili Ravi

\footnotetext{
Corresponding author: shamim@uaar.edu.pk.com 0030-9923/2019/0006-2007 \$ 9.00/0

Copyright 2019 Zoological Society of Pakistan
}

buffalo reported an in vitro block to development at about 8-16 cell stage that can be attributed to sub-optimal culture conditions (Jamil et al., 2011; Patel et al., 2013). Adequate culture medium is requisite for an in vitro system that can efficiently provide nutrients such as glucose, amino acids and fatty acids to the developing embryo. Different in vitro culture media like TCM-199, mCR2 or mSOF have been adopted for the culture of buffalo embryos. But, the main shortcoming was slow growth rate and low percentage of transferable stage embryos.

Secretory epithelial cells of the oviduct play an important role particularly during early pregnancy by secreting specific glycoproteins that are required for the embryonic development in the female reproductive tract (Murray, 1997). An ongoing hypothesis suggests that oviductal epithelial cells co-culture enhance the development of pre-implantation embryos by one or more mechanisms. Firstly, these cells produce and release specific embryotrophic factors (Oliphant, 1986) such as insulin-like growth factors (IGF), transforming growth 
factor (TGF) and leukemia inhibitory factor (LIF) that are required by early stage embryos to maintain normal rate of development (Gandolfi and Moor, 1987). Another possibility is that these cells also contribute antioxidant enzymes like manganese superoxide dismutase (MnSOD), $\mathrm{Cu}-\mathrm{Zn}$-superoxide dismutase (CuZnSOD), glutathione peroxidase (GPX), glutamyle cysteine synthetase (GCS) and catalase (CAT) which inhibit production of toxic radicals and embryotoxic substances, such as ammonia in the culture medium (Nancarrow and Hill, 1994). For efficient embryotrophic activity, recovery of oviductal epithelial cells from fresh tissue is prerequisite, which is one of the limitations of co-culture (Xu et al., 1992). Another limitation for co-culture is that culture media may get contaminated by the oviductal cells that cause risk of infecting the embryos (Avery et al., 1993). To reduce the variability, one alternative in co-culture systems could be the use of cell lines that maintain primary culture attributes. An even better alternative is the conditioned media; the spent medium collected from cultured cells has been developed and successfully used. These cultured cells secrete vast variety of proteins including growth factors, cytokines, chemokines, extracellular matrix proteins and metabolites such as lactate, pyruvic acid, amino acids, and glucose into the medium in which they grow (Freshney, 1999; Lopera-Vásquez et al., 2016) that support the early embryonic development. Conditioned medium is readily available as it can be prepared and stored, easy alternative, unaffected by freezing and thawing and same batch can be used for several replicates (Lopera-Vásquez et al., 2016; Eyestone et al., 1991).

Co-culture system/conditioned medium can be developed using oviductal cells of different species and the effect of oviductal cells on embryonic development is nonspecies-specific (Pavasuthipaisit et al., 1994). However, it has also been claimed that co-culture systems using heterologous oviductal cells monolayer may increase the risk of genetic contaminations (Nematollahi-mahani et al., 2009). Therefore, more efficient culture environment either co-cultured or conditioned with oviductal cells from same species (isologous) needs to be evaluated to alleviate the danger of genetic inter-species contamination.

In the present study, the competence of culture environment (either co-cultured or conditioned with buffalo oviductal epithelial cells) for developing preimplantation buffalo embryos in two different culture media (Synthetic Oviductal Fluid media and Medium 199) was investigated.

\section{MATERIALS AND METHODS}

\section{Collection of oocytes from buffalo ovaries}

Buffalo ovaries (900) were collected during breeding season from slaughtered animals and transferred to the IVF laboratory, Buffalo Research Institute (BRI), Pattoki within two hours in a thermos containing sterilized phosphate buffered saline (PBS) kept at $33-35^{\circ} \mathrm{C}$. Fresh PBS was used to wash the ovaries immediately after arrival. Sterile disposable plastic syringe $(10 \mathrm{ml})$ fitted with 18 gauge needle was used to aspire immature cumulusoocyte complexes (COCs) from 2-8 $\mathrm{mm}$ visible follicles. Searching for COCs were done under stereomicroscope and collected in PBS. COCs were classified as grade A, $\mathrm{B}, \mathrm{C}$ and $\mathrm{D}$, on the basis of their cumulus investment and ooplasm homogeneity (Azam et al., 2017). Only grade A and B oocytes (1000) were processed for IVM.

\section{In vitro maturation (IVM) of oocytes}

Selected COCs were washed twice in $\operatorname{PBS}\left(37^{\circ} \mathrm{C}\right)$ and twice in pre-equilibrated maturation medium: TCM-199 supplemented with $0.02 \mathrm{IU} / \mathrm{mL}$ FSH, $1 \mu \mathrm{g} / \mathrm{mL}$ estradiol$17 \beta$ (E2), $10.0 \mathrm{ng} / \mathrm{mL}$ epidermal growth factor (EGF), $50 \mu \mathrm{g} / \mathrm{mL}$ gentamicin and $10 \%$ Fetal calf serum (FCS).
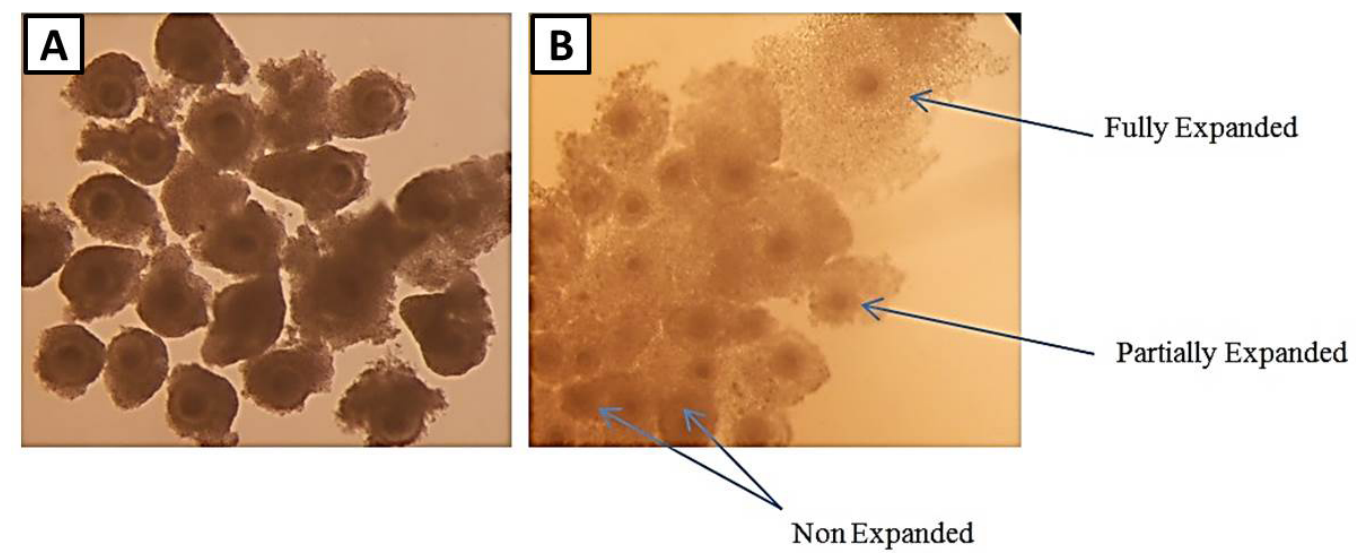

Fig. 1. Cumulus oocyte complexes (COCs) before (A) and after (B) $24 \mathrm{~h}$ of maturation. 
The washed oocytes were randomly allocated into 100 $\mu \mathrm{l}$ of respective culture droplets of each treatment group covered with sterile mineral oil (Sigma M8410) and matured in vitro in a water-jacketed incubator at $38.5^{\circ} \mathrm{C}$ under an atmosphere of $5 \% \mathrm{CO}_{2}$ in air with $95 \%$ humidity for $24 \mathrm{~h}$. After $24 \mathrm{~h}$ of maturation, cumulus cell expansion was assessed by visual assessment using stereomicroscope. Oocytes with fully and partially expanded cumulus cells were taken as mature oocytes and oocytes with no cumulus expansion were not processed further. Criterion is shown in Figure 1. Data were collected in ten independent repeats. All media and culture dishes were equilibrated at $38.5^{\circ} \mathrm{C}$ in $\mathrm{CO} 2$ incubator for at least $1-2 \mathrm{~h}$ before experiment.

\section{In vitro fertilization (IVF) of oocytes}

Three $0.5 \mathrm{ml}$ straws of cryopreserved buffalo semen were thawed in water at $37^{\circ} \mathrm{C}$ for 30 seconds. Thawed semen was placed in a $15 \mathrm{ml}$ conical tube. Spermatozoa with maximum motility were collected by swim up technique (Parrish et al., 1986). About $250 \mu \mathrm{L}$ of thawed semen was deposited at the bottom of four $15 \mathrm{~mL}$ tubes containing $3 \mathrm{~mL}$ of pre warmed sperm wash medium (TALP: modified calcium-free Tyrode's Albumin Lactate Pyruvate with $6 \mathrm{mg} / \mathrm{ml}$ BSA fraction-V). Tubes were incubated at $45^{\circ}$ angle for $30 \mathrm{~min}$. Supernatant from each tube was removed and transferred into another 15 $\mathrm{mL}$ conical tube and centrifuged at $1600 \mathrm{rpm}$ for $10 \mathrm{~min}$. The pellet obtained after centrifugation of supernatant was assessed for sperm motility, and concentration was determined using an improved Neubauer Cell Counting Chamber. Subsequently, to get a final concentration of $2 \mathrm{x}$ $10^{6}$ live sperm $\mathrm{mL}^{-1}$, the sperm pellet was re-suspended in pre-warmed fertilization TALP supplemented with $0.1 \mathrm{mM}$ hypotaurine, $0.2 \mathrm{mM}$ penicillamine, $0.01 \mathrm{mM}$ epinephrine and $10 \mu \mathrm{g} / \mathrm{mL}$ heparin.

After $24 \mathrm{~h}$ of maturation, buffalo oocytes were washed in fertilization media and were placed in fertilization droplet ( 5 COCs $/ 50 \mu \mathrm{L}$ droplet) of pre warmed fertilization media under mineral oil with final sperm concentration of $2 \times 10^{6}$ $\mathrm{mL}^{-1}$. The oocyte and spermatozoa were co-incubated at $38.5^{\circ} \mathrm{C}$ under $5 \% \mathrm{CO} 2$ with maximum humidity for $20 \mathrm{~h}$ (Gasparrini et al., 2008).

\section{Preparation of oviductal cell monolayer}

Processing of buffalo oviductal epithelial cells for preparation of monolayer was performed as described by (Lopera-Vásquez et al., 2016; Nandi et al., 2006). Oviducts ipsilateral to the corpus luteum at the mid-luteal phase of the estrous cycle were collected from buffaloes at local slaughterhouse, sealed in a plastic bag and transported to the laboratory on ice. The oviducts were washed with
Dulbecco's phosphate-buffered saline (DPBS) and extra tissue was removed. The oviducts were compressed with a glass slide and oviductal epithelial cells were extracted in a petri dish. Cells were flushed through 26-gauge needle attached to a $10 \mathrm{ml}$ syringe to get single cell suspension. The recovered cells were washed twice in wash medium (DPBS $+0.3 \%$ BSA) by centrifugation at $2000 \mathrm{x}$ for 10 min and then for $5 \mathrm{~min}$ at $1000 \mathrm{x} \mathrm{g}$ with respective culture medium. The supernatant was discarded and the cells were diluted with respective culture medium (M199+5\% FCS or SOF $+5 \%$ FCS) to a concentration of $1 \times 10^{6}$ cells/ $\mathrm{mL} .50 \mu \mathrm{L}$ of this cell suspension was then transferred to a 4-well dish (Nunc, Roskilde, Denmark) under mineral oil and incubated at $38.5^{\circ} \mathrm{C}$ in an atmosphere of $5 \% \mathrm{CO}_{2}$ in air with $95 \%$ humidity. After $72 \mathrm{~h}$ monolayer of oviductal epithelial cells was observed at the base of culture droplet.

\section{Preparation of conditioned media}

For preparation of conditioned medium of oviductal epithelial cells, oviductal cell suspension $(5 \mathrm{~mL})$ with a total of $2.5 \times 10^{6}$ cells from respective culture media (M199 $+5 \% \mathrm{FCS}$ or $\mathrm{SOF}+5 \% \mathrm{FCS}$ ) were transferred to corning culture flasks and cultured at $38.5^{\circ} \mathrm{C}$ in a humidified incubator with 5\% CO2 in air. The culture medium was renewed with respective culture media (M199+5\% FCS or SOF $+5 \%$ FCS), once after $48 \mathrm{~h}$ of culture to remove unattached cells. Culture was continued for 3 to 5 days, till they were $80-100 \%$ confluent (Lopera-Vásquez et al., 2016; Maeda et al., 1996). The cultures were centrifuged at $300 \mathrm{x} \mathrm{g}$ for $5 \mathrm{~min}$, and the supernatant was collected. Supernatant, called the conditioned medium was filtered through a 0.22 micron filter and used for embryo culture as conditioned M199 and conditioned SOF.

\section{In vitro culture (IVC) of oocytes}

After IVF, the presumptive zygotes were denuded by repeated pipetting in PBS and washed twice in culture media. Denuded presumptive zygotes (792) were transferred to the $50 \mu \mathrm{l}$ droplet of embryo culture according to the experimental group and were cultured in an incubator at $38.5^{\circ} \mathrm{C}, 5 \% \mathrm{CO}_{2}$ and $95 \%$ humidity. Experimental groups used in this study were: Group I: SOF alone, Group II: SOF + co-culture, Group III: conditioned SOF, Group IV: M199 alone, Group V: M199 + co-culture and Group VI: conditioned M199. Both culture media (SOF and M199) in all treatment groups were supplemented with 5\% FCS. On day 2 of development (Day $0=$ day of insemination) the cleavage rate (number of oocytes cleaved/total $\times 100$ COCs incubated) was observed. Further developmental stages (4-8 cell stage, $>8$ cell stage and Morula) were evaluated and recorded every other day. Criterion is shown in Figure 2. 


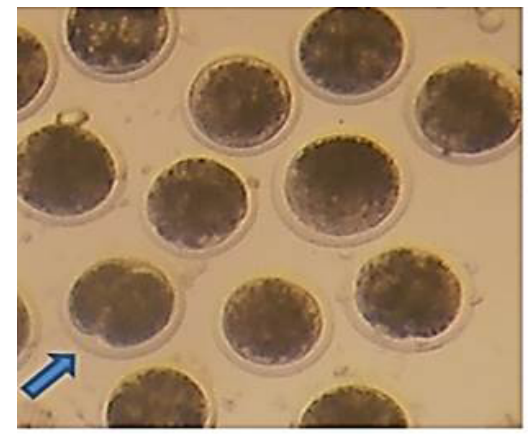

Cleavage (2-cell stage)

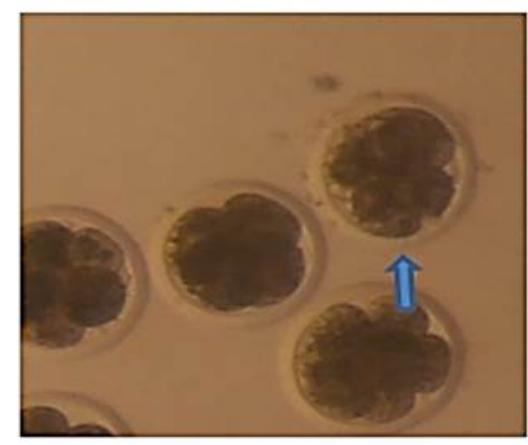

$>8$-cell stage

Fig. 2. Assessment criteria for developmental stages.

\section{Statistical analysis}

Data on all developmental stages were recorded and analyzed by one-way analysis of variance (ANOVA) at $5 \%$ level of significance. Duncan's multiple range test (DMRT) was used to compare treatment means.

\section{RESULTS}

A total of 1440 oocytes were recovered from 900 ovaries (1.6/ovary), out of which, a total of 1000 oocytes (A and B grade) were processed for in vitro maturation (IVM). Matured oocytes were inseminated and 792 presumptive zygotes were randomly placed in culture treatments (SOF alone, SOF + co-culture, Conditioned SOF, M199 alone, M199 co-culture and Conditioned M199). The ability of presumptive zygotes to develop in culture media (SOF and M199) alone, co-cultured with buffalo oviductal cells or conditioned media was studied. The data on the effect of different embryo culture systems on cleavage rate and further development of buffalo embryos (4-8 cell stage, $>8$ cell stage and Morula) are shown in Table I. Development of presumptive zygotes to the 2-cell stage in all treatment groups was similar $(\mathrm{P}>$ 0.05 ), ranging from 50 to $57 \%$ of COCs existing at the

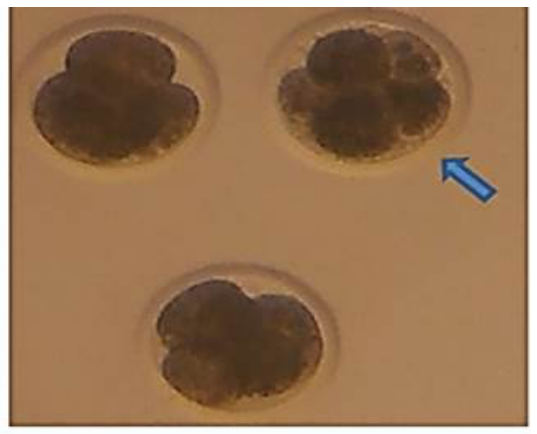

4-8 cell stage

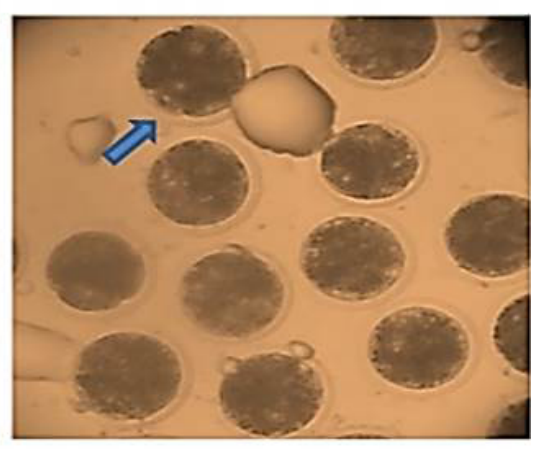

Morula

beginning of experiment. Development up to the 4- to 8 -cell stage was recorded higher $(\mathrm{P}<0.05)$ with $\mathrm{SOF}+$ coculture compared to M199 alone and conditioned M199 ( $47 \%$ vs. $35 \%$ and $39 \%$, respectively), while development in SOF co-culture, Conditioned SOF, SOF alone and M199 + co-culture groups was similar $(\mathrm{P}>0.05)$, ranging from 40 to $47 \%$.

The better efficiency of SOF co-culture and conditioned SOF was clearly evident at the $>8$ cell stage, with 34 and $36 \%$ of embryos crossing 8 cell stage compared to SOF alone, M199 +co-culture, Conditioned M199 and M199 alone supporting the development of $22 \%, 25 \%, 24 \%$ and $15 \%$ of embryos, respectively ( $\mathrm{P}$ $<0.05)$. Furthermore highest $(\mathrm{P}<0.05)$ percentage of embryos reaching to morula stage was maintained with SOF + co-culture and conditioned SOF $(27 \%$ and $25 \%$, respectively) compared to production of morula in SOF alone, M199 + co-culture and conditioned M199 and M199 alone (12\%, 16\%, 15\% and 9\%, respectively). The percentage of morula per cleaved embryos in different culture treatments is clearly depicted in Figure 3, which shows improved development of morula in SOF (coculture and/or conditioned) than with M199 (co-culture and/or conditioned) after cleavage. 
Table I.- Developmental rate of in vitro matured/fertilized buffalo oocyte in different IVC environments.

\begin{tabular}{|c|c|c|c|c|c|}
\hline \multirow[t]{2}{*}{ Treatments } & \multirow{2}{*}{$\begin{array}{l}\text { Presumptive } \\
\text { zygotes }\end{array}$} & \multicolumn{4}{|c|}{ Stages of embryo development (mean percentage \pm SEM) } \\
\hline & & $\begin{array}{l}\text { 2- Cell } \\
\text { n (\%) }\end{array}$ & $\begin{array}{c}\text { 4-8 Cell } \\
\text { n (\%) }\end{array}$ & $\begin{array}{l}>8 \text { cell } \\
\text { n (\%) }\end{array}$ & $\begin{array}{c}\text { Morula } \\
\text { n (\%) }\end{array}$ \\
\hline SOF alone & 132 & $68(51.5 \pm 2.6)$ & $54(40.9 \pm 3.5)^{\mathrm{abc}}$ & $30(22.7 \pm 2.2)^{b}$ & $16(12.1 \pm 2.3)^{\mathrm{b}}$ \\
\hline SOF + co-culture & 132 & $76(57.6 \pm 2.6)$ & $62(47.0 \pm 1.4)^{\mathrm{a}}$ & $48(36.6 \pm 2.2)^{\mathrm{a}}$ & $36(27.3 \pm 1.8)^{\mathrm{a}}$ \\
\hline Conditioned SOF & 132 & $74(56.2 \pm 2.0)$ & $60(45.3 \pm 2.3)^{\mathrm{ab}}$ & $46(34.8 \pm 1.3)^{\mathrm{a}}$ & $34(25.8 \pm 2.6)^{\mathrm{a}}$ \\
\hline M199 alone & 132 & $66(50.2 \pm 2.1)$ & $46(35.0 \pm 3.6)^{\mathrm{c}}$ & $20(15.2 \pm 2.3)^{\mathrm{c}}$ & $12(09.1 \pm 0.5)^{\mathrm{c}}$ \\
\hline M199+ co-culture & 132 & $74(56.1 \pm 1.0)$ & $54(40.9 \pm 1.0)^{\mathrm{abc}}$ & $34(25.8 \pm 1.7)^{b}$ & $22(16.7 \pm 1.6)^{b}$ \\
\hline Conditioned M199 & 132 & $72(54.6 \pm 1.5)$ & $52(39.4 \pm 1.3)^{\mathrm{bc}}$ & $32(24.2 \pm 1.2)^{\mathrm{b}}$ & $20(15.2 \pm 1.6)^{b}$ \\
\hline
\end{tabular}

a,b,c, the values with different superscripts in the same coloumn differ significantly $(\mathrm{P}<0.05)$. n, number of embryos.

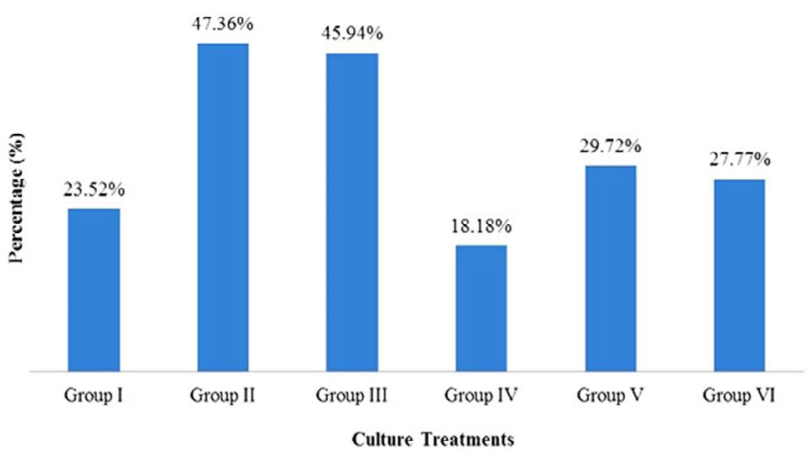

Fig. 3. Percentage of morula per cleaved zygotes in different IVC treatments (Group I, SOF alone; Group II, SOF+Co-culture; Group III, Conditioned SOF; Group IV, M199 alone; Group V, M199+Co-culture; Group VI, Conditioned M199).

\section{DISCUSSION}

The intrinsic quality of oocytes determines the embryo yield (Rizos et al., 2002); while post fertilization embryo culture is substantial in regulating the embryo quality (Lonergan et al., 2003). In vivo, the oviductal and uterine fluid provide appropriate amino acids, lipids, carbohydrates, proteins, nutrients, hormones, growth factors and ions for pre- and post-compaction embryonic development, respectively (Gandolfi and Moor, 1987; Ozdaş et al., 2006). In vitro, the culture medium has been developed to greatly mimic the in vivo conditions. In this regard, various culture media like TCM-199 medium, Charles Rosenkrans (CR) medium, ChatotZiomekBavister (CZB) medium and Synthetic oviductal fluid (SOF) medium were utilized for buffalo embryo culture and were found proficient for the development of buffalo embryos. However, despite of continuous refinement in the culture media, in vitro cultured embryos are still subjected to suboptimal conditions in the laboratory that is evident from low blastocyst yields around 10 (Nandi et al., 2002) to $20 \%$ (Gasparrini et al., 2003) which is much lower than the blastocyst yields ( $\sim 30$ to $40 \%$ ) observed in cattle (Yang et al., 1998).

The incompetency of in vitro culture systems to sustain development of embryos from cleavage through to blastocyst is the result of insufficiency of the culture systems used. To provide a culture environment that closely imitate in vivo environment of development still needs further investigations. In this respect, the system that more closely mimic the in vivo conditions such as co culture with feeder cells is of relevance (Rizos et al., 2002). Among different feeder cells studied, the oviductal cells were superior to other somatic cells and the embryotrophic properties of oviductal epithelial cells has been well defined in a range of species (Nematollahimahani et al., 2009; Eyestone and First, 1989; Rexroad and Powell, 1993; Sakkas et al., 1989; Smith et al., 1992; Kitiyanant et al., 1995), suggesting tissue specific but not species-specific effect (Pavasuthipaisit et al., 1994).

In present study, culture of buffalo oocytes using buffalo oviductal epithelial cells or conditioned medium promoted development as compared to culture in medium alone. The definitive role of conditioned medium was sufficiently clear not only for crossing the developmental block, but also getting percentage of transferable stage embryos similar to buffalo oviductal epithelial cell cocultures. Results are in line with previous report in which it has been reported that medium conditioned by bovine oviductal cells was as effective as cell co-culture in supporting embryo development to the compact morula and blastocyst stages in bovine (Rexroad and Powell, 1993). The ability of conditioned media to perform as efficiently as direct cell co-culture could be the result of enough availability of embryotrophic factors in conditioned 
media or during the conditioning period epithelial cells adequately removed inhibitory factors from the media.

The definite mechanism by which enhanced early embryo development is obtained stays uncertain; however, the putative mechanisms include detoxification and procurement of required metabolites and particular development stimulators into the surrounding medium (Malayer et al., 1988). Moreover, the co-cultured cells during the course of their own proliferation can potentially provide bioactive factors which are absent in IVC media alone. Consequently, the conditioned media will have the components secreted/excreted by cells, like numerous enzymes, growth factors, cytokines, chemokines, lactate, glutamate and hormones or other soluble mediators. These factors are fundamental in the processes of cell growth, differentiation, invasion and angiogenesis by regulating cell-to-cell and cell-to-extracellular matrix interactions (Dowling and Clynes, 2011).

It has been documented that embryo metabolism is different in the pre- and post-compaction stage. Within female reproductive tract, the nutrients availability changes according to preferences of nutrient by the developing embryo. In the oviductal fluid relatively higher concentrations of pyruvate and lactate, and low concentration of glucose are found. In contrast, relatively low levels of pyruvate and lactate, and a higher concentration of glucose were found in uterine fluid. Therefore, appropriate media composition is also prerequisite for efficient embryo development at different stages of development in vitro (Lane and Gardner, 2007).

While comparing two basic media used in present study, it has been observed that the cleavage rate of buffalo embryos was unaffected by any of the treatments tested either using M199 or SOF as culture media. At 4- to 8-cell stage, significant difference was found between M199 alone and SOF (co-cultured or conditioned) and it became more prominent while reaching $>8$-cell stage embryos. One major component that is present in the formulations of M199 is glucose that is absent in SOF (Parrish et al., 1989). During early development there is low level respiratory rates and limited ability to metabolize glucose as a source of energy. Glycolysis of glucose substrate may increase oxidative stress which could not be compensated by antioxidant enzymes contributed by co-cultured cells which may interfere with reactive oxygen species (ROS) production and consumption balance. In this way quality of embryos is affected which is prominent during stages of embryo genome activation, which hampered the subsequent embryo development. Further in this study, when SOF medium was conditioned/co-cultured, pronounced effect was observed for crossing 8-16 cell block and further development as compared with conditioned/co-cultured
M199.

We conclude from this study that the IVC media, SOF favoured the buffalo embryo development; either cocultured or conditioned with buffalo oviductal epithelial cells. Conditioned media proved competent like co-culture system and can be used as an alternative for developing pre-implantation buffalo embryos. The system of isologous oviductal cells or medium conditioned by these cells has further advantages of being free of the risks of genetic contamination. However, further work is desired to expose the function and nature of secretary factors released by secretary epithelial cells of buffalo oviduct.

\section{Statement of conflict of interest}

Authors have declared no conflict of interest.

\section{REFERENCES}

Avery, B., Greve, T., Ronsholt, L. and Botner, A., 1993. Virus screening of a bovine in vitro embryo production system. Vet. Rec., 132: 660. https://doi. org/10.1136/vr.132.26.660

Asma-ul-Husna, Ansari, M.S., Rakha, B.A., Ejaz, R., U. Nemat and Akhter, S., 2017. Melatonin supplementation in extender enhances the post thaw quality of buffalo bull spermatozoa. Pakistan J. Zool., 49: 171-175.

Azam, A., Husna, A.U., Shahzad, Q., Akhtar, T., Haq, E., Ullah, N. and Akhter, S., 2017. Efficiency of fatty acid-free defined system for in vitro maturation of buffalo oocytes. J. Anim. Pl. Sci., 27: 112-118.

Bilal, M.Q., Suleman, M. and Raziq, A., 2006. Buffalo: Black gold of Pakistan. Livest. Res. Rural Dev., 18: 140-151.

Dowling, P. and Clynes, M., 2011. Conditioned media from cell lines: A complementary model to clinical specimens for the discovery of disease-specific biomarkers. Proteomics, 11: 794-804. https://doi. org/10.1002/pmic. 201000530

Eyestone, W.H. and First, N.L., 1989. Co-culture of early cattle embryos to the blastocyst stage with oviductal tissue or in conditioned medium. J. Reprod. Fertil., 75: 715-720. https://doi.org/10.1530/jrf.0.0850715

Eyestone, W.H., Jones, J.M. and First, N.L., 1991. Some factors affecting the efficacy of oviduct tissue conditioned medium for the culture of early bovine embryos. J. Reprod. Fert., 92: 59-64. https://doi. org/10.1530/jrf.0.0920059

Freshney, R.I., 1999. Culture of animal cells: A manual of basic technique, $5^{\text {th }}$ ed. Hoboken, John Wiley and Sons, New York.

Gandolfi, F. and Moor, R.M., 1987. Stimulation of early 
embryonic development in the sheep by co-culture with oviduct epithelial cells. J. Reprod. Fertil., 81: 23-28. https://doi.org/10.1530/jrf.0.0810023

Gasparrini, B., Rosa, A.D., Attanasio, L., Boccia, L., Palo, R.D., Campanile, G. and Zicarelli, L., 2008. Influence of the duration of in vitro maturation and gamete co-incubation on the efficiency of in vitro embryo development in Italian Mediterranean Buffalo (Bubalus bubalis). Anim. Reprod. Sci., 105: 354-364. https://doi.org/10.1016/j. anireprosci.2007.03.022

Gasparrini, B., Sayoud, H., Neglia, G., de Matos, D.G., Donnay, I. and Zicarelli, L., 2003. Glutathione synthesis. Theriogenology, 60: 943-952. https:// doi.org/10.1016/S0093-691X(03)00098-0

Jamil, H., Samad, H.A., Rehman, N.U., Qureshi, Z.I. and Lodhi, L.A., 2011. Effect of somatic cell type sand culture medium on in vitro maturation, fertilization and early development capability of buffalo oocytes. Pak. Vet. J., 31: 105-108.

Kitiyanant, Y., Tocharus, C., Areekijseree, M. and Pavasuthipaisit, K., 1995. Swamp buffalo oocytes form transvaginal ultrasound guided aspiration fertilized and co-cultured in vitro with bovine oviductal epithelial cells. Theriogenology, 43: 250. https://doi.org/10.1016/0093-691X(95)92404-W

Lane, M. and Gardner, D., 2007. Embryo culture medium: Which is the best? Pract. Res. Clin. Obstet. Gynaecol., 21: 83-100. https://doi.org/10.1016/j. bpobgyn.2006.09.009

Lonergan, P., Rizos, D., Gutiérrez-Adán, A., Fair, T. and Boland, M.P., 2003. Effect of culture environment on embryo quality and gene expression-experience from animal studies. Reprod. Biomed. Online, 7: $\quad 657-663 . \quad$ https://doi.org/10.1016/S14726483(10)62088-3

Lopera-Vásquez, R., Hamdi, M., Fernandez-Fuertes, B., Maillo, V., Beltrán-Breña, P., Calle, A., Redruello, A., López-Martín, S., Gutierrez-Adán, A., Yañez-Mó, M., Ramirez, M.A. and Rizos, D., 2016. Extracellular vesicles from BOEC in in vitro embryo development and quality. PLoS One, 11: e0148083. https://doi.org/10.1371/journal. pone. 0148083

Maeda, J., Kotsuji, F., Negami, A., Kamitami, N. and Tominaga, T., 1996. In vitro development of bovine embryos in conditioned media from bovine granulosa cells and Vero cells cultured in exogenous protein and amino acid-free chemically defined human tubal fluid medium. Biol. Reprod., 54: 930936. https://doi.org/10.1095/biolreprod54.4.930

Malayer, J.R., Hansen, P.J. and Buhi, W.C., 1988.
Secretions of proteins by cultured bovine oviducts collected from estrus through early diestrus. $J$. exp. Zool., 248: 345-353. https://doi.org/10.1002/ jez. 1402480313

Murray, M.K., 1997. Morphological features of epithelial cells in the sheep isthmus oviduct during early pregnancy. Anat. Rec., 247: 368378 . $\quad \mathrm{https}: / /$ doi.org/10.1002/(SICI)10970185(199703)247:3<368::AID-AR8>3.0.CO;2-Q

Nancarrow, C.D. and Hill, J.L., 1994. Co-culture, oviduct secretion and the function of oviductspecific glycoproteins. Cell. Biol. Int., 18: 11051114. https://doi.org/10.1006/cbir.1994.1037

Nandi, S., Kumar, V.G., Gupta, P.S.P., Ramesh, H. and Manjunatha, B.M., 2006. Effect of ovine follicular fluid peptide on preantral, oocyte and somatic cells culture in buffalo (Bubalus bubalis). Anim. Reprod., 3: 61-69.

Nandi, S., Raghu, H.M., Ravindranatha, B.M. and Chauhan, M.S., 2002. Production of buffalo (Bubalus bubalis) embryos. Reprod. Domest. Anim., 37: 65-74. https://doi.org/10.1046/j.14390531.2002.00340.x

Nematollahi-Mahani, S.N., Pahang, H., Moshkdanian, G. and Nematollahi-Mahani, A., 2009. Effect of embryonic fibroblast cell co-culture on development of mouse embryos following exposure to visible light. J. Assist. Reprod. Genet., 26: 129-135. https:// doi.org/10.1007/s10815-008-9290-6

Oliphant, G., 1986. Biochemistry and immunology of oviductal fluid. In: The Fallopian tube: Basic studies and clinical contributions (ed. A.M. Siegler). Futura, Mount Kisco, New York.

Ozdaş, O.B., Pabuccuoglu, S. and Ileri, I.K., 2006. Effects of monopotasium phosphate and oviduct cells on the in vitro fertilized mice embryos development. Medycyna Wet., 62: 281-284.

Parrish, J.J., Susko-Parrish, J.L., Leibfreid-Rutledge, M.L., Crister, E.S., Eystone, W.H. and First, N., 1986. Bovine in vitro fertilization with frozenthawed semen. Theriogenology, 25: 591-600. https://doi.org/10.1016/0093-691X(86)90143-3

Parrish, J.J., Susko-Parrish, J.L. and First, N.L., 1989. Capacitation of bovine sperm by heparin: Inhibitory effect of glucose and role of intracellular $\mathrm{pH}$. Biol. Reprod., 41: 683-699. https://doi.org/10.1095/ biolreprod41.4.683

Patel, A.V., Singh, K.P., Varshney, N., Chauhan, M.S., Palta, P., Singla, S.K. and Manik, R.S., 2013. Expression patterns of transcription factors during zygotic genome activation in buffalo (Bubalus bubalis) embryos produced in vitro. Indian $J$. 
Biotechnol., 12: 323-329.

Pavasuthipaisit, K., Lhuangmahamongkol, S., Tocharus, C., Kitiyanant, Y. and Prempree, P., 1994. Porcine oviductal cells support in vitro bovine embryo development. Theriogenology, 41: 1127-1138. https://doi.org/10.1016/S0093-691X(05)80035-4

Rexroad, C.E. and Powell, A.M., 1993. Development of ovine embryos co-cultured on oviductal cells, embryonic fibroblasts, or STO cell monolayers. Biol. Reprod., 49: 789-793. https://doi.org/10.1095/ biolreprod49.4.789

Rizos, D., Ward, F., Duffy, P., Boland, M.P. and Lonergan, P., 2002. Consequences of bovine oocyte maturation, fertilization or early embryo development in vitro versus in vivo: Implications for blastocyst yield and blastocyst quality. Mol. Reprod. Dev., 61: 234-248. https://doi.org/10.1002/ mrd.1153
Sakkas, D., Batt, P.A. and Cameron, A.W.N., 1989. Development of preimplantation goat (Capra hireus) embryos in vivo and in vitro. J. Reprod. Fert., 87: 359-365. https://doi.org/10.1530/ jrf.0.0870359

Smith, S., Schmidt, M., Purwantara, B. and Greve, T., 1992. Oviduct epithelial cell co-culture of early porcine embryos. Acta Vet. Scand., 33: 349-355.

Xu, K.P., Yadav, B.R., Rorie, R.W., Plante, L., Betteridge, K.J. and King, W.A., 1992. Development and viability of bovine embryos derived from oocytes matured and fertilized in vitro and co-cultured with bovine oviductal epithelial cells. J. Reprod. Fertil., 94: 33-43. https://doi.org/10.1530/jrf.0.0940033

Yang, X., Kubota, C., Suzuki, H., Taneja, M., Bols, P.E. and Presicce, G.A., 1998. Control of oocyte. Theriogenology, 49: 471-82. https://doi. org/10.1016/S0093-691X(97)00419-6 